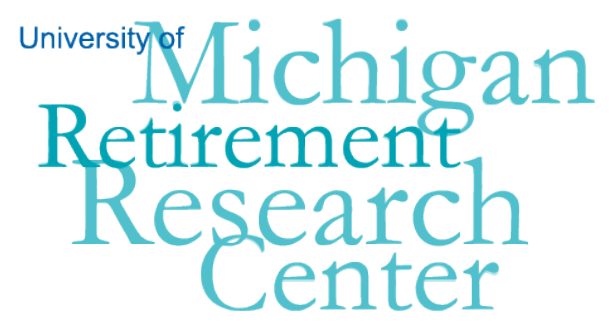

Working Paper

WP 2012-268

Mismeasurement of Pensions Before and After Retirement: The Mystery of the Disappearing Pensions with Implications for the Importance of Social Security as a Source of Retirement Support

Alan L. Gustman, Thomas L. Steinmeier, and Nahid Tabatabai

\begin{tabular}{|l|l|}
\hline $\mathrm{M}$ & $\mathrm{R}$ \\
\hline $\mathrm{R}$ & $\mathrm{C}$ \\
\hline
\end{tabular}

Project \#: UM12-10 



\title{
Mismeasurement of Pensions Before and After Retirement: The Mystery of the Disappearing Pensions with Implications for the Importance of Social Security as a Source of Retirement Support
}

\author{
Alan L. Gustman \\ Dartmouth College \\ Thomas L. Steinmeier \\ Texas Tech University \\ Nahid Tabatabai \\ Dartmouth College
}

May 2013

\author{
Michigan Retirement Research Center \\ University of Michigan \\ P.O. Box 1248 \\ Ann Arbor, MI 48104 \\ www.mrrc.isr.umich.edu
}

(734) 615-0422

\section{Acknowledgements}

This work was supported by a grant from the Social Security Administration through the Michigan Retirement Research Center (Grant \# 5 RRC08098401-04-00). The findings and conclusions expressed are solely those of the author and do not represent the views of the Social Security Administration, any agency of the Federal government, or the Michigan Retirement Research Center. 


\title{
Mismeasurement of Pensions Before and After Retirement: The Mystery of the Disappearing Pensions with Implications for the Importance of Social Security as a Source of Retirement Support
}

\begin{abstract}
A review of the literature suggests that when pension values are measured by the wealth equivalent of promised DB pension benefits and DC balances for those approaching retirement, pensions account for more support in retirement than is suggested when their contribution is measured by incomes received directly from pension plans by those who have already retired. Estimates from the Health and Retirement Study (HRS) for respondents in their early fifties suggest that pension wealth is about 82 percent as valuable as Social Security wealth. In data from the Current Population Survey (CPS), for members of the same cohort, measured when they are 65 to 69, pension incomes are about 58 percent as valuable as incomes from Social Security. Our empirical analysis uses data from the HRS to examine the reasons for these differences in the contributions of pensions as measured in income and wealth data. Key factors accounting for these difference include: a difference in methodology between surveys affecting what is included in pension income; some pension wealth "disappears" at retirement because respondents change their pension into other forms that are not counted as pension income; and the form of annuitization may influence the measure of pension income. A series of caveats notwithstanding, the bottom line is that CPS data on pension incomes received in retirement understates the full contribution pensions make to supporting retirees.
\end{abstract}

\section{Citation}

Gustman, Alan, Thomas Steinmeier and Nahid Tabatabai. "Mismeasurement of Pensions Before and After Retirement: The Mystery of the Disappearing Pensions with Implications for the Importance of Social Security as a Source of Retirement Support.” MRRC Working Paper No. 2012-268. Michigan Retirement Research Center. Ann Arbor, MI. 2013. 


\section{Introduction}

The aim of this paper is to increase understanding of the importance of pensions and Social Security as sources of income and wealth in retirement. We also hope to increase understanding of pension dynamics as covered individuals proceed from employment through retirement, either collecting or transforming their pensions.

We begin by focusing on the apparent discrepancies between published data documenting pension coverage and plan value between surveys of current workers and surveys of retirees. Consider, for example, the following simple comparisons: The widely read Social Security publication "Income of the Population Over 55, 2008 ," p. 37, suggests that 39.2 percent of units (couple or single member households) with at least one member aged 65 to 69 received pension or other retirement benefits beyond their Social Security. In contrast, data from the Health and Retirement Study (HRS) suggest that about three fourths of households from that same cohort had a pension from a current, last or previous job when they were ages 51 to 56 (Gustman, Steinmeier and Tabatabai, 2010a, Table 5.12), and 52.7 percent of respondents (not households) had a live pension from a current or previous job (Table 5.11).

There are analogous differences in plan values. For example, pensions appear to be much more important relative to Social Security when measured for those approaching retirement in the HRS than when they are measured among retirees by the Social Security Administration using CPS data. For those ages 65 to 69, the CPS suggests income from pensions is about 59 percent as large as income from Social Security. ${ }^{1}$ In contrast, for a similar population HRS data suggest the present value of expected pensions is 67 percent of the present value of their future Social Security payments. Adding the values of pensions and IRAs, as CPS income data does, in HRS

\footnotetext{
${ }^{1}$ Pensions account for 15.1 percent of total income while Social Security represents 25.4 percent of total income. (Social Security Administration, 2010, p. 316.)
} 
wealth data, the value of pensions and IRAs together is 90 percent of the value of Social Security (Gustman, Steinmeier and Tabatabai, 2010a, Table 12.1A). ${ }^{2}$

These differences may result from differences in the importance of pensions vs. Social Security in income data vs. their importance in wealth data, from differences when measures are taken for households in their early fifties vs. households in their late sixties or early seventies resulting from disposition of pensions in intervening years, from differences when expected flows are compared to realized incomes, from differences in requirements for inclusion of a benefit in CPS vs. HRS data, or for other reasons. Our goal is to determine the importance of each of these explanations.

We examine various measures of pensions and Social Security to suggest the importance of potential reasons for these differences. To determine whether the measured differences in the importance of pensions vs. Social Security are due to differences between surveys, or are the result of comparing measures based on incomes with measures based on the wealth equivalents of expected benefits, we do two things. First, using measures of income received by those ages 65 to 69 in 2006, we compare the importance of pension and Social Security income in the Health and Retirement Study (HRS) with corresponding data from the Census. Second, we compare the relative importance of pensions and Social Security when based on income or expected wealth within one survey, the Health and Retirement Study.

To isolate the effect of the time in the lifecycle the data are collected, we examine differences in the relative importance of pensions vs. Social Security using wealth values collected at different stages of the employment cycle, when workers are on the job and have not yet neared retirement age, just before retirement, and just after retirement. We also consider differences in wealth when measured based on expectations as recorded just before retirement vs. payment received, as recorded in the income section of the HRS for

\footnotetext{
${ }^{2}$ A number of studies use data from the Health and Retirement Study to examine the relative importance of pensions and Social Security wealth as sources of support in retirement. For early studies along these lines, see Gustman, Mitchell, Samwick and Steinmeier (1999) and Gustman and Steinmeier (1999).
} 
individuals who have retired. These latter comparisons are for the same individuals at different stages of their life cycle.

It is not a mystery why differences in plan balances might arise when comparing account values before vs. after retirement, especially among those with a defined contribution (DC) plan. Consider DC plans from previous employment held by respondents aged 51 to 56 when first observed in 2004. According to HRS data, more than half these balances are either rolled over into an IRA after exit or are cashed out (Gustman, Steinmeier and Tabatabai, 2010b, Table 11.3D). Moreover, the pattern of withdrawals from DC plans may be very uneven and difficult to detect. Poterba, Venti and Wise (2011) suggest that many households may put off withdrawals from DC pensions until well after retirement age. Work by Purcell and Iams (2013) suggests that ignoring irregular withdrawals may cause incomes to be understated by up to 3 percent.

But DC plans represent a minority of the pension wealth held by those who are currently of retirement age, even among those who have recently reached retirement age. Among the Early Boomer cohort in the HRS, those ages 51 to 56 in 2004, defined benefit (DB) plans still account for two thirds of their pension wealth. In HRS data on pensions held in last or previous jobs, cash outs and roll overs account for somewhat less than one fifth of the value of DB pensions at the time they are disposed of.

An obvious question, one that we address in this paper, is whether the pension benefits of those approaching retirement age are systematically overstated in HRS wealth data. Could it be that the discrepancies between reported pension coverage and plan values, especially DB plan values, are the result of reporting error, presumably by workers who have not yet focused on their pensions? After all, there is ample evidence of reporting error in plan coverage and in plan value (Gustman and Steinmeier, 2004, 2005; Gustman, Steinmeier and Tabatabai, 2010a). Or are there systematic forces at work?

Section II discusses possible reasons for differences among surveys in the measured importance of pensions. Section III compares the importance of pensions and Social Security in the retirement incomes of those 
65 to 69. The importance of pensions and Social Security in incomes after retirement is compared with their importance in wealth measures in Section IV. Section V uses data from the Health and Retirement Study to compare plan coverage and plan values as evaluated in the period before retirement with comparable measures of coverage and plan wealth based on data collected after retirement. Section VI compares measures of pension wealth collected for members of a panel, restricted to those with a single pension plan who provide consistent answers to questions about plan type. Section VII concludes.

\section{Reasons for differences in pension values.}

Consider a number of reasons why pension measures may differ between surveys, when measured in the context of surveys of income vs. wealth, and when measured at different ages, even for the same individuals when observed before and after retirement.

\section{A. Differences in concept and measurement.}

There are some reasons why pension values reported before retirement may be underestimates. Before retirement, many surveys focus on pension coverage from the current job, but do not keep track of pensions held on previous jobs. For example, surveys based on establishment data focus only on the value of the pension from current employment. ${ }^{3}$ Similarly, most household surveys of individuals taken before retirement that are aimed at evaluating pensions ignore dormant but live pensions from previous jobs, and are especially likely to ignore defined benefit pensions, whether from current or previous jobs. ${ }^{4}$ At the same time, pension income reported after retirement often includes the value of payments from all plans, whenever the job was held. If pension

\footnotetext{
${ }^{3}$ According to data from the Health and Retirement Study, in 2004, 46.8 percent of respondents ages 51 to 56 had a pension on a current job; 15.9 percent had a pension that was still alive from a job previously held but not yet in pay status; and 3.5 percent had a pension in pay status. These are not mutually exclusive categories, so 52.7 percent of respondents had a pension that was still live. In addition, 62.4 percent of respondents ever had pension coverage, some having cashed out or converted their pension into some other form. (Gustman, Steinmeier and Tabatabai, 2010a, Table 5.11.)

${ }^{4}$ Still other studies may ignore pensions, or a portion of pensions, when considering the sources of retirement wealth. For example, Bricker et al. $(2010,2012)$ use the Survey of Consumer Finances to examine the changes in retirement assets over the course of the Great Recession. Yet DB pensions from current and previously held jobs are excluded from Bricker et al.'s measures of total wealth. This is despite the fact that at the onset of the recession, DB wealth accounted for two thirds of total pension wealth for those approaching retirement age (Gustman, Steinmeier and Tabatabai, 2010a, Table 13.1).
} 
coverage is more comprehensive after than before retirement, this would increase the measured value of pensions in retirement in surveys of retirees compared to current workers.

In contrast, there are a number of reasons why the value of pensions after retirement may be underestimated, especially if evaluation is based on sources of income realized in retirement. First, not all pensions are in pay status, even after the person leaves the pension job. When a pension is not in pay status, it is commonly ignored in questions related to pension incomes. Even when a pension is in pay status, a survey may not include income originating from the pension. ${ }^{5}$ Another factor is that actual benefit payments may be reduced from the pension called for by the simple benefit formula advertised by the firm. For example, this will happen when an annuity is chosen that differs from the single life annuity emphasized by a plan. An annuitized benefit will be reduced when, as required by law, a spouse or survivor benefit is chosen. The reduction will depend on the ages of each spouse and on whether the survivor benefit is half the main benefit, whether it is two thirds as in Social Security, or whether the annual benefit will remain unchanged upon the death of the covered worker. There may be further reductions if the retiree chooses a guaranteed minimum payout period. To be sure, these differences in payout due to actuarial adjustments do not create actual differences in the present value of benefits. But one must know the details of the respondent's choice as to spouse and survivor benefits and other characteristics of the annuity, and adjust using appropriate life tables. That is, a proper analysis would not just consider the annual pension payment, but would also consider the value of payments that will be made in future years to the surviving spouse. Typically these details are not available on a survey and no such adjustment is

\footnotetext{
${ }^{5}$ For example, as pointed out by Anguelov, Iams and Purcell (2012), CPS data on pension incomes in retirement count only annuitized income, but not irregular income from pensions, such as periodic withdrawals from 401k accounts. Iams and Purcell (2013) estimate that for the one fifth of families that receive distributions from retirement accounts, their incomes would be about fifteen percent higher if these distributions were counted, suggesting that incomes for all retirees may be undercounted by about 3 percent. Some of that additional income includes return on own contributions, however. Nevertheless, undercounting irregular income from retirement accounts may become a more important problem over time because funds in DC pension accounts often are not claimed until the covered worker reaches age 70, when withdrawals are mandated. Indeed, a disproportionate amount of benefits may not be withdrawn until even later (Poterba, Venti and Wise, 2011). Since defined contribution plans have grown in importance over time, the effect of ignoring irregular withdrawals will become more important as members of younger cohorts retire and age.
} 
made. Indeed, in the absence of the appropriate information on the HRS as to the details of the annuity, our pension wealth estimates do not include such adjustments either.

\section{B. Rollovers, cash-outs, and other changes in pensions at job termination}

In addition, some pensions are rolled over or cashed out at retirement. Unless the survey carefully traces IRA balances and other assets back to the pension plan where they originated, and continues to keep track of those funds, as a result of these modes of disposition, there will be a reduction in the measured contribution of pensions to post retirement incomes. Of course, the role of cash-outs in influencing subsequent wealth is even more difficult to evaluate.

Table 1 describes the disposition of pensions as reported by respondents who were members of the original HRS cohort and were included in a pension in 1992. The reports are made in the wave just after the respondent leaves his/her Wave 1 job.

Adding the total values reported in the top panel of column 1, the total value of DB pensions reported at disposition per HRS respondent (whether covered by a pension or not) is $\$ 64,379$. From column 1 , we can calculate that only 6 percent of DB plan values $[(2127+1578) / 64,379]$ are lost to rollovers or are cashed out.

The total value of DC pensions is $\$ 15,347$. Of that total, 42 percent of the balances was left in the account to accumulate and similarly 42 percent was rolled over into an IRA. The remaining 16 percent was used to purchase an annuity or withdrawn. To be sure, assets that are cashed out may simply be spent. Or they may have been deposited, used to pay off a mortgage, or saved in other ways. On the other hand, funds left in a DC account or rolled over into an IRA are even more likely to be available to support consumption in retirement. 
Table 1: Disposition of Pension from HRS Wave 1 Job at Termination, as Reported from Wave 2 to Wave 8

\begin{tabular}{|c|c|c|c|}
\hline Disposition of Pension & $\begin{array}{c}\text { Overall Mean } \\
\text { (1992 Dollars) }\end{array}$ & $\begin{array}{c}\text { Percent Nonzero } \\
\text { Observations }\end{array}$ & $\begin{array}{c}\text { Mean of Nonzero } \\
\text { Observations } \\
\text { (1992 Dollars) }\end{array}$ \\
\hline & \multicolumn{3}{|c|}{ Defined Benefits } \\
\hline Expect Future Benefit & 14,054 & 12.3 & 114,022 \\
\hline Receive Current Benefit & 46,620 & 36.7 & 126,895 \\
\hline Received Cash Settlement & 2,127 & 1.7 & 49,538 \\
\hline Rolled into IRA & 1,578 & 4.3 & 90,237 \\
\hline \multirow[t]{2}{*}{ Total } & 64,379 & a & 380,692 \\
\hline & \multicolumn{3}{|c|}{ Defined Contribution } \\
\hline Amount in Account & 6,401 & 12.6 & 51,268 \\
\hline Rolled into IRA & 6,503 & 10.1 & 63,627 \\
\hline Converted to Annuity & 1,471 & 1.8 & 82,219 \\
\hline Withdrew the Money & 972 & 5.6 & 17,223 \\
\hline Total & 15,347 & a & 214,337 \\
\hline Number of Observations & \multicolumn{3}{|c|}{2515} \\
\hline
\end{tabular}

The sample includes respondents with one pension plan from a current job in HRS Wave 1 who terminated that job after Wave 1 and before Wave 8 .

Percent nonzero observations is the ratio of the number of nonzero observations to the total sample size.

a. The different waves of the HRS are not consistent in whether they permit multiple responses. Consequently, the percent nonzero observations cannot be summed. There also may be a minor effect on the totals reported in the table. 
Conversion of DC plans into some other form (other than leaving the account to accumulate) will be a much more important reason why the value of DC plans in retirement falls below the value initially stated by currently employed respondents than is the case for DB pensions. Since DB pensions were by far the dominant plan type for this cohort, as they are for current retirees, turnover of pension assets into other forms at retirement is less significant in explaining why pension values are lower in surveys of retirees, although it also contributes to the explanation.

Adding the total values in column 1 and dividing into the sum of the values for categories associated with a change in the form of the asset out of a pension, about 16 percent of total pension assets no longer remain in the form of a pension at termination.

We should also note here that in instances where current pensions were cashed out soon after the individual left the job, the questions asked by the HRS on disposition of pensions will capture that termination of the pension. However, if at the time the individual left the job he/she reported that the plan remained intact but was not in pay status, and at some later time after the individual left the job that plan was cashed out, these estimates would overstate the value of pensions for that individual. We estimate the importance of delays in claiming or reporting later in the paper.

\section{Other sources of differences between benefits measured before and after retirement.}

There are other reasons to expect discrepancies between pension values reported before and after retirement, especially when expected plan values are reported a number of years before retirement. Defined contribution balances change with contributions and with returns on assets. In addition, pension plans may have changed between the time the individual is surveyed while still at work, and the time the individual has retired. Still another complication is that some who left their pension job may not collect for a number of years. In addition, the individual may have reported an expected retirement age before retirement that differs from the actual retirement age. For example, when interviewed before retirement, a 58 year old individual may report an 
expected benefit on the assumption that he will remain at work until age 62. But a layoff, or ill health, or other circumstance may lead to an actual retirement age before then. The expected benefit values before retirement and the actual benefits found after retirement may then differ because they refer to different retirement dates, and thus different amounts of tenure on the job, and perhaps also to different final earnings.

Errors in reported plan type may also affect the findings. Evidence suggests that respondents have considerable difficulty in identifying plan type (Gustman, Steinmeier and Tabatabai, 2010a, chapter 7). To separate the effects of errors in reported plan type from systematic factors affecting the comparison of values before and after retirement per se, a number of the comparisons made in this paper are restricted to those who consistently report plan type in Wave 1 and at termination. Similar problems may arise when respondents have more than one plan. In particular, there may not be sufficient information to match each individual pension over time. To reduce errors from this source, the comparisons we make in panel data are restricted to those who report only one pension. Ten percent of the original sample had more than one plan. Restricting the panel to those with only one plan creates less of a problem for the original HRS cohort than would be the case when analyzing members of cohorts that are much younger, where multiple plans are more common. There also are other issues that may affect comparisons between expected benefits at a time before retirement and actual benefits realized after retirement. An important problem is that it is not always clear whether the individual is reporting expected benefits in current or future dollars. ${ }^{6}$ A related problem is differential availability of cost of living adjustments. Historically, partial, ad hoc, cost of living adjustments were available to workers in the private sector. They are much less common today and are no longer available for most private sector workers with a DB pension. However, cost of living adjustments are still available for public sector workers. If cost of living benefits are added into post retirement pension incomes, but are not considered by those reporting expected pension benefits, this would lead to a finding of higher benefits when pensions are measured after retirement than before.

\footnotetext{
${ }^{6}$ When calculating wealth values of defined benefit pensions, we treat all reports of future benefits as if they were made in future dollars. Thus these values are discounted by 5.8 percent.
} 
Table 2. Social Security and Pension Income (or Wealth) as a Percentage of Income (or Wealth)*

\begin{tabular}{|c|c|c|c|c|}
\hline & Based & Income & Based & Wealth \\
\hline & $\begin{array}{c}\text { CPS } \\
\text { (Income) } \\
2006 \\
\text { (Ages 65-69) }\end{array}$ & $\begin{array}{c}\text { HRS } \\
\text { (Income) } \\
2006 \\
\text { (Ages 65-69) }\end{array}$ & $\begin{array}{c}\text { HRS } \\
\text { (Present Value) } \\
2006 \\
\text { (Ages 65-69) }\end{array}$ & $\begin{array}{c}\text { HRS } \\
\text { (Present Value) } \\
\text { as of } 1992 \text { in } \\
2006 \text { dollars } \\
\text { when } 51 \text { to } 55\end{array}$ \\
\hline $\begin{array}{l}\text { Social Security Benefits } \\
\text { (Ratio of Social Security to } \\
\text { Income or Wealth) }\end{array}$ & $(25.7 \%)$ & $\begin{array}{c}14,922 * * \\
(23.8 \%)\end{array}$ & $\begin{array}{l}278,594 \\
(24.7 \%)\end{array}$ & $\begin{array}{l}268,493 \\
(28.3 \%)\end{array}$ \\
\hline $\begin{array}{l}\text { Pension Benefits } \\
\text { (Ratio of Pension Benefits to } \\
\text { Income or Wealth) }\end{array}$ & $(14.8 \%)$ & $\begin{array}{l}9,556 \\
(15.3 \%)\end{array}$ & $\begin{array}{l}196,904 \\
(17.4 \%)\end{array}$ & $\begin{array}{l}218,948 \\
(23.1 \%)\end{array}$ \\
\hline Total Income or Wealth & & 62,661 & $1,130,106$ & 947,558 \\
\hline $\begin{array}{l}\text { Ratio of Average of Pension } \\
\text { to Social Security Value }\end{array}$ & 0.58 & 0.64 & 0.71 & 0.82 \\
\hline Number of Households & 7,493 & 2,304 & 2,304 & 2,304 \\
\hline $\begin{array}{l}\text { Distribution of Ratios of } \\
\text { Pension to Social Security } \\
\text { Values for Households with } \\
\text { positive values for each } \\
\text { asset.*** } \\
25 \text { percent } \\
50 \text { percent } \\
75 \text { percent } \\
\text { Mean } \\
\text { Std. dev. } \\
\text { (No. of Obs.) }\end{array}$ & & $\begin{array}{l}0.33 \\
0.74 \\
1.43 \\
\\
1.26 \\
1.76 \\
882 \\
\end{array}$ & $\begin{array}{l}0.23 \\
0.60 \\
1.28 \\
\\
0.96 \\
1.10 \\
1392 \\
\end{array}$ & $\begin{array}{c}0.19 \\
0.55 \\
1.32 \\
\\
0.98 \\
1.21 \\
1503 \\
\end{array}$ \\
\hline
\end{tabular}

*At least one member of the household falls within the indicated age range. Variables are defined in the Appendix.

**For purpose of comparison with the Social Security Administration's results based on the CPS, HRS results are un-weighted. Weighted results are very similar.

***HRS observations with the highest and lowest $1 \%$ of pension wealth, Social Security wealth, and ratios of pensions to Social Security have been eliminated from their respective calculations. 


\section{Pension and Social Security Income in the Current Population Survey and in the Health and}

\section{Retirement Study.}

In Table 2, we report shares of income due to Social Security and pensions for households with at least one person aged 65 to 69 in $2006 .^{7}$ The data in column 1 are reported by the Social Security Administration using data from the Current Population Survey. Shares calculated using data from the Health and Retirement Study are reported in column 2. In CPS data, the share of income due to Social Security is 25.7 percent, and the share due to pensions is 14.8 percent. From HRS data, 23.8 percent of income is due to Social Security and 15.3 percent is due to pensions.

There are a number of reasons for the differences reported between the surveys. Income is defined differently between the two surveys, so the denominators used to calculate income and pension shares will be different between the surveys. ${ }^{8}$ Also, as noted in our discussion of sources of measurement error, the surveys differ in their methodology for counting Social Security and pension income. For example, the CPS disregards irregular withdrawals from pensions, while the HRS does not. In the end, the share of income due to pensions differs by 0.5 percentage points between the surveys. The share of income due to Social Security differs by 1.9 percentage points.

To abstract from the effects of differences in the definition of income between the surveys, it is instructive to consider the ratio of pension income to Social Security income. In the CPS data, pension values are 58 percent

\footnotetext{
${ }^{7}$ Note the following differences between the data in Tables 1 and 2, and between the wealth estimates taken in 1992 and 2006 in Table 2. Table 1 includes respondents with a current pension who had reported only one plan. This table indicates how that one plan is disposed of upon respondents' job termination during Waves 2 to 8 . Table 2 includes respondents ages 51 to 55 in Wave 1. Pension wealth in this table includes the present value of pensions from current/last and previous three pension jobs, as reported initially in Wave 1. The pension wealth in 2006 (ages 65-69) also includes the present value of any pension from the current job held in 2006, from any job that was terminated after Wave 1, and from up to three previous pension jobs respondents reported in their initial interview in 1992, including previous pensions for those who were not working in 1992. In addition, by 2006, some respondents will have retired, so that their previously reported pensions are lost through conversion to IRAs and annuities, or have been cashed out. Another issue is created because some of the respondents who stayed on the same job, holding a pension that they report did not change, nevertheless reported a zero plan number when they were asked about the number of plans in 2006. As a result, the pension wealth from their current job as reported previously has disappeared in 2006.

${ }^{8}$ Income is reported for last month in the HRS, while in the CPS, income is based on a report for last year.
} 
of the value of Social Security. In HRS data, the pension value is 64 percent of the value of Social Security

benefits. Note that the CPS includes regular income from IRA and Keogh plans under pension income, while in our calculations using the HRS data, we did not, making the actual differences between the surveys even wider.

Despite various differences in definition, the share of income from pensions among those 65 to 69 differs by only one half of a percentage point between the HRS and CPS. The share of income due to Social Security differs by more. It is higher in CPS data. This only partially explains why the ratio of income from pensions to Social Security is substantially lower in the CPS than in the HRS.

\section{Social Security and Pensions in HRS Wealth vs. Income Data}

Column 3 reports the share of total wealth due to Social Security and pensions when respondents were observed in $2006 .{ }^{9}$ Column 4 reports the results when they were observed in the first wave of the HRS in $1992 .^{10}$

Social Security accounts for a larger share of wealth than income. ${ }^{11}$ The difference is about 0.9 percentage points $(24.7-23.8)$. Similarly, pensions account for a 2.1 percent larger share of wealth than of income (17.4 - 15.3). In HRS data, the ratio of pension wealth to wealth from Social Security benefits is .71, a higher ratio than the ratio of pension income to Social Security income in the HRS at .64.

\footnotetext{
${ }^{9}$ Social Security wealth considers own, spouse and survivor benefits for couples, and uses life tables for each spouse in determining the wealth equivalent of these benefits for the household. Pension wealth estimates take the report of expected benefits and discount those benefits as if the respondent would be receiving a single life annuity.

${ }^{10}$ The wealth estimates in the last two columns of Table 2 are both discounted to 2006 . Note that the Social Security wealth estimates in 2006 ignore any benefits already paid previous to 2004. Despite that, Social Security wealth is higher in the 2006 estimates than in the 1992 estimates, even though these comparisons are for members of the same cohort. Both estimates of Social Security wealth are computed on the assumption that the individual retires immediately and claims benefits at the earliest age possible. As a result, the Social Security wealth estimates for 2006 take account of additional benefits resulting from additional work by those individuals who had not retired by 1992. The effect is to raise the present value of Social Security in 2006, thereby reducing the value of the ratio of pensions to Social Security in 2006 relative to 1992.

${ }^{11}$ When comparing Social Security and pensions as a share of income in column 2, with Social Security and pensions as a share of wealth in columns 3 and 4, one should recognize the differences in the denominator. Earnings play an important role in the income of those ages 65 to 69 (column 2), but are not included in the wealth of those 65 to 69 (columns 3 or 4 ). Also note that the share of Social Security and of pensions in income are both influenced by date of claiming.
} 


\section{Estimated Contributions of Pensions to Retirement Wealth Before and After Retirement.}

The last two columns of Table 2, both based on HRS data, again pertain to the cohort aged 65 to 69 in 2006. Column 3 reports wealth values based on observations reported in 2006, while column 4 provides wealth values based on data reported in 1992. Comparing these values, one can determine the changes in the present values of pensions reported before and after retirement. The value of pension wealth reported just after retirement, when respondents were 65 to 69 , is about 10 percent lower than the value reported before retirement when the respondents were 51 to 55 . Specifically, when reported in 1992, the value of pensions was $\$ 218,948$, falling to $\$ 196,904$ when reported in 2006. In contrast, summing the values in Table 1 for various outcomes at disposition of pensions, we can compute what part of the assets initially held in the form of pensions in 1992 remained in that form by 2006, and what part is transformed into some other asset. Specifically, from Table 1 we have $(14,054+$ $46,620+6,401) /(64,379+15,347)$ remaining in the form of pension wealth between ages 51 to 55 and 65 to 69 . That is, pensions lose about 16 percent of their value at the time of disposition because they are transformed into other forms. 
Table 3: Respondents with Pension from Current Job in Wave 1 by Wave Job Is Terminated Or the Individual Leaves the Survey

\begin{tabular}{|c|c|}
\hline Respondents & Number of Respondents \\
\hline Respondents with one pension plan & 3209 \\
\hline Terminated wave 1 job & 2515 \\
\hline Left job between wave 1 \& wave 2 & 597 \\
\hline Left job between wave 2 \& wave 3 & 505 \\
\hline Left job between wave 3 \& wave 4 & 427 \\
\hline Left job between wave 4 \& wave 5 & 338 \\
\hline Left job between wave 5 \& wave 6 & 324 \\
\hline Left job between wave 6 \& wave 7 & 197 \\
\hline Left job between wave 7 \& wave 8 & 127 \\
\hline Left the survey before terminating wave 1 job & 377 \\
\hline Left the survey before wave 2 & 124 \\
\hline Left the survey before wave 3 & 86 \\
\hline Left the survey before wave 4 & 66 \\
\hline Left the survey before wave 5 & 37 \\
\hline Left the survey before wave 6 & 26 \\
\hline Left the survey before wave 7 & 15 \\
\hline Left the survey before wave 8 & 23 \\
\hline $\begin{array}{l}\text { Did not terminate wave 1 job \& did not leave } \\
\text { the survey }\end{array}$ & 317 \\
\hline
\end{tabular}


Table 4: Number of Respondents with a Pension Plan in Wave 1 from Current Job who Terminated Their Job Just Before the Indicated Wave, by Plan and Disposition of Plan: Wave 2 to Wave 8

\begin{tabular}{|c|c|c|c|c|c|c|c|c|c|c|}
\hline Respondents who reported & Wave 2 & $\begin{array}{c}\text { Wave } \\
3 \\
\end{array}$ & Wave 4 & Wave 5 & Wave 6 & Wave 7 & Wave 8 & $\begin{array}{l}\text { Sub- } \\
\text { Total } \\
\end{array}$ & Missing & Total \\
\hline Pension Coverage in Wave 1 & 597 & 505 & 427 & 338 & 324 & 197 & 127 & 2515 & $\begin{array}{c}377+317= \\
694\end{array}$ & 3209 \\
\hline $\begin{array}{l}\text { Pension Coverage at } \\
\text { termination }\end{array}$ & 498 & 447 & 393 & 323 & 307 & 187 & 118 & 2273 & - & \\
\hline \multicolumn{11}{|l|}{ DB } \\
\hline Any DB in Wave 1 & $\begin{array}{c}392 \\
\$ 134 \mathrm{k}\end{array}$ & $\begin{array}{c}322 \\
\$ 124 k\end{array}$ & $\begin{array}{c}277 \\
\$ 105 \mathrm{k}\end{array}$ & $\begin{array}{c}210 \\
\$ 110 \mathrm{k}\end{array}$ & $\begin{array}{c}205 \\
\$ 101 \mathrm{k}\end{array}$ & $\begin{array}{c}122 \\
\$ 92 \mathrm{k}\end{array}$ & $\begin{array}{c}74 \\
\$ 89 \mathrm{k}\end{array}$ & $\begin{array}{c}1602 \\
\$ 116 \mathrm{k}\end{array}$ & $\begin{array}{c}420 \\
\$ 102 k\end{array}$ & $\begin{array}{l}2022 \\
\$ 112 \mathrm{k}\end{array}$ \\
\hline Any DB at termination & 336 & 290 & 242 & 216 & 187 & 113 & 66 & 1450 & - & \\
\hline $\begin{array}{l}\text { DB in Wave } 1 \text { and at } \\
\text { termination }\end{array}$ & 270 & 227 & 200 & 169 & 145 & 91 & 48 & 1150 & - & \\
\hline \multicolumn{11}{|l|}{ DC } \\
\hline Any DC in Wave 1 & $\begin{array}{c}222 \\
\$ 34 \mathrm{k}\end{array}$ & $\begin{array}{r}199 \\
\$ 64 \mathrm{k} \\
\end{array}$ & $\begin{array}{c}161 \\
\$ 30 \mathrm{k}\end{array}$ & $\begin{array}{r}139 \\
\$ 40 \mathrm{k} \\
\end{array}$ & $\begin{array}{l}132 \\
\$ 30 \mathrm{k}\end{array}$ & $\begin{array}{c}83 \\
\$ 36 \mathrm{k} \\
\end{array}$ & $\begin{array}{c}55 \\
\$ 29 \mathrm{k} \\
\end{array}$ & $\begin{array}{c}991 \\
\$ 39 \mathrm{k}\end{array}$ & $\begin{array}{l}286 \\
\$ 40 \mathrm{k}\end{array}$ & $\begin{array}{l}1277 \\
\$ 39 k\end{array}$ \\
\hline Any DC at termination & 187 & 171 & 174 & 139 & 133 & 87 & 62 & 953 & - & \\
\hline $\begin{array}{l}\text { DC in Wave } 1 \text { and at } \\
\text { termination }\end{array}$ & 116 & 114 & 106 & 87 & 70 & 52 & 32 & 577 & - & \\
\hline
\end{tabular}




\section{Further explanation of changes in pensions between pre- and post-retirement within the HRS}

panel.

By restricting participation in HRS panel data to those who provide consistent answers, these data can be used to provide further insight into the reasons for the decline in the value of pensions as respondents age from their early fifties into their late sixties. We will examine expected pension wealth in 1992, expected pension wealth in the year just before leaving the firm, pension wealth at exit from the firm for those who claim benefits immediately, pension wealth after leaving the firm for those who delayed claiming after leaving the firm, and the value of any pension cash-out taken.

Most of the remaining analysis will focus on respondents (not households) ages 51 to 61 in 1992. Enough time has passed that almost all members of the original HRS cohort have retired.

The sample used in the remaining analysis will be restricted in a number of ways to clarify the picture as to which changes underlie the findings. In all tables, individuals are restricted to those reporting only one pension plan. (This restriction is not too severe since only 10 percent of this cohort had more than one pension at the outset of the survey.) But other restrictions may vary from table to table for reasons that will become apparent. Within each table, the underlying samples are consistent, but they are not always consistent across tables. All comparisons are made in present value terms.

Tables 3 and 4 describe the origins of the sample. As seen in Table 3, the HRS includes 3,209 respondents in the original wave of the survey (1992) who had a current job and reported having only one pension plan on that job. Of these, 2,515 left their wave 1 job by 2006, Wave 8 of the survey, when they ranged in age between 65 and 75. An additional 377 left the survey before terminating their wave 1 job, and 317 had not yet terminated their job as of 2006. From Table 4, 242 (subtotal in row 1 minus row 2) respondents who were recorded as having a pension at Wave 1 denied having a pension at the time their job was terminated. 
Most commonly, individuals retired from their pension jobs in the first few waves after the initial survey in 1992. In the first three waves of the survey, three fifths of those who reported one pension on their current job in the initial wave of the survey retired from their pension job.

Within the group of 2,515 with one pension on a current job in 1992, from line 3,1,602 respondents reported having a defined benefit pension on that job, with a present value of $\$ 116,000$. By the eighth wave, 1,450 respondents, including some who had not reported having a DB plan in Wave 1, reported having left their Wave 1 job and, at the time they left, having had a defined benefit pension. Thus between the first wave and the final wave at termination, the number of covered workers who reported having a pension fell by 10 percent, and the number of workers reporting a DB pension fell by a similar amount. But again, these are not the same respondents in both waves. Some of the respondents reporting a DB plan at termination had reported a DC plan in 1992.

Of the 1,450 who reported having left their job and having had a defined benefit plan at termination, 1,150 had also reported having a DB plan both in 1992 and at job termination. This will be the sample that underlies much of our later work, concentrating on those who consistently reported a DB plan throughout the panel.

Appendix Table 1 reports the differences in plan value by plan type for those who stayed with the survey and left their job before the end of the survey; left the survey before leaving their job; or never left their job before their final interview. From row 2, average plan value for those with a DB plan who terminated their job by Wave 8 was $\$ 114,000$. Among those reporting a defined benefit pension in the first wave of the survey, 243, or 12 percent of the sample, left the survey before terminating their job. In the initial wave of the survey, their pensions were worth $\$ 107,000$. Nine percent of those with a DB plan in Wave 1 remained with their employers throughout the survey. In the initial wave of the survey, their pensions were worth $\$ 96,000$.

Columns 3 and 4 of Appendix Table 1 present findings for those who reported a defined contribution pension in Wave 1. Account balances reported in the first wave of the survey are similar whether the respondent 
remained in the survey but left the job before the end of the survey, left the survey before leaving their job, or remained with the survey but did not leave their job. These balances average $\$ 39,000$ across all three groups. Reporting error remains a problem, especially with regard to plan type. Returning to Table 4, there are 1,602 who reported a defined benefit pension in Wave 1 (row 3, column 8), and who remained throughout the period of analysis, and who terminated their employment by Wave 8 . Of this group, 1,150 (row 5, column 8) also reported having a defined benefit pension at termination. On the other hand, $452(1,602-1,150)$ members of the survey declared having a pension in Wave 1 and in Wave 1 declared that their pension was a DB plan, but did not declare having a DB pension at the time they terminated their employment from the pension job. In addition, 300 $(1,450-1,150)$ reported a DB pension at termination, but did not report a DB pension in the first wave of the survey. This latter difference is probably a reflection of reporting error rather than a gain in DB coverage on the same job, although in a few cases it might reflect the individual's response to having vested in the interim. In forming the group of panel members who consistently reported only one defined benefit plan, 28 percent of the observations that reported a DB plan in Wave 1 will have been lost as a result of inconsistent reporting of plan type $(1-(1,150 / 1,602))$.

Having examined the differences in frequency of pensions from the initial wave of the survey through termination, we now turn to Table 5A. There we describe the numbers and percentages of respondents experiencing different types of disposition of defined benefit pensions at termination. Table 5A builds on the information provided in Table 1. It reports findings for those who consistently indicated they had one DB plan. Reading down each column, we see the share of those who first reported leaving their job in the relevant wave who still expected future benefits; who immediately received benefits, who received cash settlements, whose DB plan was rolled over into an IRA, and whose plan experienced some other fate.

From the last column of Table 5A, row 2, we see that 69 percent of respondents' DB plans began paying benefits at termination, while from row 1, 20 percent expected benefits in the future. In 12 percent of the cases 
(last column, sum of bottom three rows), the individual received a cash settlement, the plan was rolled over into an IRA, or there was some other disposition that did not involve paying benefits. ${ }^{12}$ Also notice by scanning across the columns that 10 to 14 percent of plans are cashed out, rolled over or otherwise claimed no matter what wave the individual leaves the job. Glancing across row 2, the later a person left the job, the greater the probability that benefits would be received upon exit, and the lower the probability that the individual would be expecting future benefits.

Thus, we find that in 12 percent of the cases of those who had a defined benefit pension just before termination, at termination the benefit was transformed into a state that would not count as pension income after retirement. Nevertheless, when pensions are converted to cash settlements, rolled over into an IRA or converted in other ways, the pension is still the origin of the income or wealth reported in retirement. As a result, the importance of pensions in retirement would be understated.

Table 5B provides the analogous results for those who reported a defined contribution plan both in the initial wave of the survey and upon leaving their job. Here only 35 percent of the respondents reported leaving their assets to accumulate in a DC plan (last column, row 1), and another 35 percent (last column, rows 2 plus 4 ) rolled the balance over into an IRA or converted it to an annuity, forms that would be picked up as sources of retirement income by the CPS; but pensions would not be credited as the source.

\footnotetext{
${ }^{12}$ Since only one answer was permitted in the early waves of the HRS as to disposition of the pension, there are two sources of error in trying to trace through the value of DB plans ending in different states. On the one hand, given the small size of cash settlements permitted by DB plans, especially in the early 1990s, these figures likely overstate the share of benefit amounts that went into cash settlements. On the other hand, since only one outcome could be selected, partial cashouts of DB plans are ignored, leading to an undercount of the value of cashouts.
} 
Table 5A: Disposition of Plan for 1,150 Respondents with One DB Plan in Wave 1 Who Also Had a DB Plan Upon Leaving Their Current Job, who Terminated Their Job Just before the Indicated Wave: Wave 2 to Wave 8

\begin{tabular}{|c|c|c|c|c|c|c|c|c|}
\hline $\begin{array}{l}\text { Disposition of DB Pensions } \\
\text { at termination from Table } \\
4\end{array}$ & Wave 2 & Wave 3 & Wave 4 & Wave 5 & Wave 6 & Wave 7 & Wave 8 & Total \\
\hline Expecting future benefits & $\begin{array}{c}82 / 270 \\
30 \%\end{array}$ & $\begin{array}{c}49 / 227 \\
22 \%\end{array}$ & $\begin{array}{c}40 / 200 \\
20 \%\end{array}$ & $\begin{array}{c}26 / 169 \\
15 \%\end{array}$ & $\begin{array}{c}17 / 145 \\
12 \%\end{array}$ & $\begin{array}{l}9 / 91 \\
10 \%\end{array}$ & $\begin{array}{l}6 / 48 \\
13 \%\end{array}$ & $\begin{array}{c}229 / 1150 \\
20 \%\end{array}$ \\
\hline Receiving benefits & $\begin{array}{c}159 / 270 \\
59 \%\end{array}$ & $\begin{array}{c}154 / 227 \\
68 \%\end{array}$ & $\begin{array}{c}140 / 200 \\
70 \%\end{array}$ & $\begin{array}{c}120 / 169 \\
71 \%\end{array}$ & $\begin{array}{c}111 / 145 \\
77 \%\end{array}$ & $\begin{array}{c}72 / 91 \\
79 \%\end{array}$ & $\begin{array}{c}37 / 48 \\
77 \%\end{array}$ & $\begin{array}{c}793 / 1150 \\
69 \%\end{array}$ \\
\hline Cash settlements & $\begin{array}{c}16 / 270 \\
6 \%\end{array}$ & $\begin{array}{c}16 / 227 \\
7 \%\end{array}$ & $\begin{array}{c}13 / 200 \\
7 \%\end{array}$ & $\begin{array}{c}7 / 169 \\
4 \%\end{array}$ & $\begin{array}{c}7 / 145 \\
5 \%\end{array}$ & $\begin{array}{c}5 / 91 \\
5 \%\end{array}$ & $\begin{array}{c}2 / 48 \\
4 \%\end{array}$ & $\begin{array}{c}66 / 1150 \\
6 \%\end{array}$ \\
\hline Rolled over into IRA & $\begin{array}{c}2 / 270 \\
1 \%\end{array}$ & $\begin{array}{c}1 / 227 \\
0 \%\end{array}$ & $\begin{array}{c}4 / 200 \\
2 \%\end{array}$ & $\begin{array}{c}5 / 169 \\
3 \%\end{array}$ & $\begin{array}{c}4 / 145 \\
3 \%\end{array}$ & $\begin{array}{c}2 / 91 \\
2 \%\end{array}$ & $\begin{array}{c}0 / 48 \\
0 \%\end{array}$ & $\begin{array}{c}18 / 1150 \\
2 \%\end{array}$ \\
\hline Other & $\begin{array}{c}11 / 270 \\
4 \%\end{array}$ & $\begin{array}{c}7 / 227 \\
3 \%\end{array}$ & $\begin{array}{c}3 / 200 \\
2 \%\end{array}$ & $\begin{array}{c}11 / 169 \\
7 \%\end{array}$ & $\begin{array}{c}6 / 145 \\
4 \%\end{array}$ & $\begin{array}{c}3 / 91 \\
3 \%\end{array}$ & $\begin{array}{c}3 / 48 \\
6 \%\end{array}$ & $\begin{array}{c}44 / 1150 \\
4 \%\end{array}$ \\
\hline
\end{tabular}


Table 5B: Disposition of Plan for 577 Respondents with One DC Plan in Wave 1 Who Also Had a DC Plan Upon Leaving Their Current Job, who Terminated Their Job Just before the Indicated Wave: Wave 2 to Wave 8

\begin{tabular}{|c|c|c|c|c|c|c|c|c|}
\hline $\begin{array}{l}\text { Disposition of DC } \\
\text { Pensions at termination } \\
\text { from Table } 4 \\
\end{array}$ & Wave 2 & Wave 3 & Wave 4 & Wave 5 & Wave 6 & Wave 7 & Wave 8 & Total \\
\hline Left to accumulate & $\begin{array}{c}34 / 116 \\
29 \%\end{array}$ & $\begin{array}{c}41 / 114 \\
36 \%\end{array}$ & $\begin{array}{c}42 / 106 \\
40 \%\end{array}$ & $\begin{array}{c}29 / 87 \\
33 \%\end{array}$ & $\begin{array}{l}22 / 70 \\
31 \%\end{array}$ & $\begin{array}{c}24 / 52 \\
46 \%\end{array}$ & $\begin{array}{l}9 / 32 \\
28 \%\end{array}$ & $\begin{array}{c}201 / 577 \\
35 \%\end{array}$ \\
\hline Rolled over into IRA & $\begin{array}{c}24 / 116 \\
21 \%\end{array}$ & $\begin{array}{c}41 / 114 \\
36 \%\end{array}$ & $\begin{array}{c}35 / 106 \\
33 \%\end{array}$ & $\begin{array}{c}29 / 87 \\
33 \%\end{array}$ & $\begin{array}{c}26 / 70 \\
37 \%\end{array}$ & $\begin{array}{l}14 / 52 \\
27 \%\end{array}$ & $\begin{array}{c}12 / 32 \\
38 \%\end{array}$ & $\begin{array}{c}181 / 577 \\
31 \%\end{array}$ \\
\hline Withdrew the money & $\begin{array}{c}25 / 116 \\
22 \%\end{array}$ & $\begin{array}{c}14 / 114 \\
12 \%\end{array}$ & $\begin{array}{c}17 / 106 \\
16 \%\end{array}$ & $\begin{array}{c}16 / 87 \\
18 \%\end{array}$ & $\begin{array}{c}10 / 70 \\
14 \%\end{array}$ & $\begin{array}{c}10 / 52 \\
19 \%\end{array}$ & $\begin{array}{l}1 / 32 \\
3 \%\end{array}$ & $\begin{array}{c}93 / 577 \\
16 \%\end{array}$ \\
\hline Converted to annuity & $\begin{array}{c}5 / 116 \\
4 \%\end{array}$ & $\begin{array}{c}6 / 114 \\
5 \%\end{array}$ & $\begin{array}{c}2 / 106 \\
2 \%\end{array}$ & $\begin{array}{c}3 / 87 \\
3 \%\end{array}$ & $\begin{array}{c}1 / 70 \\
1 \%\end{array}$ & $\begin{array}{c}3 / 52 \\
6 \%\end{array}$ & $\begin{array}{c}2 / 32 \\
6 \%\end{array}$ & $\begin{array}{c}22 / 577 \\
4 \%\end{array}$ \\
\hline Other & $\begin{array}{c}28 / 116 \\
24 \%\end{array}$ & $\begin{array}{c}12 / 114 \\
11 \%\end{array}$ & $\begin{array}{c}10 / 106 \\
9 \%\end{array}$ & $\begin{array}{l}4 / 87 \\
5 \%\end{array}$ & $\begin{array}{c}11 / 70 \\
16 \%\end{array}$ & $\begin{array}{l}1 / 52 \\
2 \%\end{array}$ & $\begin{array}{l}8 / 32 \\
25 \%\end{array}$ & $\begin{array}{c}80 / 577 \\
14 \%\end{array}$ \\
\hline
\end{tabular}


Next, we turn to Tables 6A. Once again, we restrict the sample to individuals who consistently report plan type, having reported they had a defined benefit plan both at the earlier period of observation and at termination, or similarly for a defined contribution plan. Table 6A, for those with a defined benefit plan, includes respondents who reported receiving benefits in the wave when they first reported having left their pension job, or having received a cash settlement upon leaving. Findings in Table 7 are for those who did not begin receiving benefits from their DB plan just after the wave they retired, reporting they expect future benefits. These respondents first report receiving benefits at some future wave, or report having cashed out their plan at some time in the future.

In Table 6A we compare the expected present values of defined benefit pensions reported in the first wave of the survey with (1) expected values recorded just before retirement, and with (2) expected present values recorded just after retirement. The top panel refers to individuals with a DB plan who did not cash out their benefit. The bottom panel reports results for the $\mathbf{6}$ percent of those with a DB plan who did cash out their benefits at termination. Remember we are using a sample of individuals who are covered by only a single defined benefit plan in 1992, thereby avoiding any ambiguity as to which plan the respondent is reporting on. This is very important in tracing plan values.

The present value of benefits is based on reports of annual benefits. Moving across row 1, we see that the present value of benefits expected in the first wave of the survey declines with the year the respondent left the pension job. Row 2 reports the present value of expected benefits as reported in the wave just before retirement. Row 3 reports the present value of benefits received after retirement, based on the first year of actual benefits reported in the first year after job termination. Values are all reported in 1992 dollars. Values reported in different rows may differ either because different annual benefits were expected at different times, or because the expected retirement ages differed between waves, or from the actual retirement age. 
Comparing rows 1 and 2, the present value of the expected pension is higher when reported in the wave just before retirement than when reported in the first wave the respondent was in the survey. Although the differences vary by wave, the expected DB pension value reported in the wave just before retirement is about 6 percent higher than the expected pension value reported when first entering the survey. The average ratio of row 3 to row 1, pension wealth based on pension income reported after retirement to pension wealth based on the annual benefit expected in wave 1, is reported in row 4 of Table 6A. From the last column, row 4 , the average of the ratios is 1.69 . Looking at the columns in rows 4 and 5, the ratios are not significantly different between those retiring in different waves. Typically, ratios are within one standard deviation of the ratio reported in each wave.

Table 6B pertains to those with a defined contribution plan. Moving across the rows, Table 6B shows that the values of DC accounts are sharply higher for those retiring later. Consistent with the likely effects of accrued interest or investment returns and continuing deposits, a comparison between values in rows 1 and 2 suggests the value of DC accounts doubled between the time the individual was first observed in the survey and the wave just before retirement. At retirement some of that benefit is cashed out, so that balances after retirement reported in row 3 are below the balances reported just before retirement in row 2 .

There is a 6 percent gain in expected $D B$ pension value between the first wave of the survey and the year before retirement. This gain would lead one to expect pension values measured among near retirees to be larger than pension values measured among those on the job in their early fifties. Thus this difference cannot explain why pension values reported by retirees are smaller than pension values reported by current workers. Similarly, pension wealth calculated from pension values reported after retirement is almost 2.2 percent higher than pension wealth calculated based on expected pensions in the first wave of the survey. Nor can the difference between the account balances in DC plans between the first wave and last wave on the job explain why pension values are lower when calculated based on pension incomes after retirement, rather than pension wealth values recorded before retirement. 
Table 6A: Present Value of Defined Benefit Plan Before Retirement from Current Job in Wave 1, the Wave Just Before Retirement, and At Job Termination, for those Receiving Benefits Just After Retirement: Wave 2 to Wave $8^{*}$

\begin{tabular}{|c|c|c|c|c|c|c|c|c|}
\hline & Wave 2 & Wave 3 & Wave 4 & Wave 5 & Wave 6 & Wave 7 & Wave 8 & Total $* *$ \\
\hline Receiving Benefits & & & & & & & & \\
\hline $\begin{array}{l}\text { PV of expected benefit before retirement (in } \\
\text { Wave 1) }\end{array}$ & $\$ 169 \mathrm{k}$ & $\$ 156 \mathrm{k}$ & $\$ 117 \mathrm{k}$ & $\$ 117 k$ & $\$ 122 \mathrm{k}$ & $\$ 127 \mathrm{k}$ & $\$ 91 \mathrm{k}$ & $\$ 136$ \\
\hline $\begin{array}{l}\mathrm{PV} \text { of expected benefit in wave just before } \\
\text { retirement }\end{array}$ & 169 & 155 & 128 & 136 & 131 & 123 & 93 & 144 \\
\hline $\begin{array}{l}\text { PV of benefit receipts after retirement (at job } \\
\text { termination) }\end{array}$ & 176 & 136 & 121 & 116 & 134 & 125 & 113 & 139 \\
\hline $\begin{array}{l}\text { Ratio of PV of benefits after retirement (row } 3 \text { ) } \\
\text { to PV in Wave } 1 \text { (row } 1 \text { ). }\end{array}$ & 1.62 & 1.42 & 1.69 & 1.47 & 2.04 & 1.83 & 2.40 & 1.69 \\
\hline Standard Deviation & 2.27 & 1.72 & 2.47 & 1.52 & 3.04 & 2.47 & 2.73 & 2.39 \\
\hline Number of observations & 157 & 128 & 107 & 91 & 82 & 51 & 28 & 634 \\
\hline$\underline{\text { Received Cash Settlements }}$ & & & & & & & & \\
\hline $\begin{array}{l}\text { PV of expected benefit before retirement (in } \\
\text { Wave 1) }\end{array}$ & $\$ 107 k$ & $\$ 124 \mathrm{k}$ & $\$ 123 k$ & $-* * *$ & - & - & - & $\$ 115$ \\
\hline $\begin{array}{l}\mathrm{PV} \text { of expected benefit in wave just before } \\
\text { retirement }\end{array}$ & 107 & 95 & 153 & - & - & - & - & 113 \\
\hline $\begin{array}{l}\mathrm{PV} \text { of cash outs after retirement (at job } \\
\text { termination) }\end{array}$ & 56 & 41 & 89 & - & - & - & - & 60 \\
\hline $\begin{array}{l}\text { Ratio of cash outs after retirement (row } 3 \text { ) to } \\
\text { PV of expected benefits before retirement (row } \\
\text { 1) }\end{array}$ & 0.48 & 0.79 & 0.84 & - & - & - & - & 1.02 \\
\hline Standard Deviation & 0.62 & 0.76 & 0.72 & - & - & - & - & 1.85 \\
\hline Number of observations & 15 & 14 & 10 & - & - & - & - & 47 \\
\hline
\end{tabular}

* The sample includes respondents who reported receiving benefits or receiving a cash settlement at job termination. The sample is restricted to those who reported a DB plan in Wave 1, in the wave just before retirement, and at retirement. 
**Observations with a ratio of total benefits that is in the highest and lowest $1 \%$ are excluded. ***Samples with less than 5 observations are not included. 
Table 6B: Account Balances Before Retirement from Current Job in Wave 1, the Wave Just Before Retirement, and At Job Termination: Wave 2 to Wave $8^{*}$

\begin{tabular}{|c|c|c|c|c|c|c|c|c|}
\hline & Wave 2 & Wave 3 & Wave 4 & Wave 5 & Wave 6 & Wave 7 & Wave 8 & Total** \\
\hline $\begin{array}{l}\text { Account Balances Left to Accumulate } \\
\text { Account balances before retirement (in Wave 1) }\end{array}$ & $\$ 50 \mathrm{k}$ & $\$ 27 \mathrm{k}$ & $\$ 23 \mathrm{k}$ & $\$ 54 \mathrm{k}$ & $\$ 29 k$ & $\$ 52 \mathrm{k}$ & $\$ 70 \mathrm{k}$ & $\$ 39 \mathrm{k}$ \\
\hline Account balances in wave just before retirement & 50 & 29 & 53 & 101 & 63 & 113 & 147 & 82 \\
\hline $\begin{array}{l}\text { Account balances after retirement (at job } \\
\text { termination) }\end{array}$ & 42 & 38 & 23 & 88 & 28 & 58 & 79 & 45 \\
\hline $\begin{array}{l}\text { Ratio: Average Account balances after } \\
\text { retirement to balances before retirement (in } \\
\text { Wave 1) }\end{array}$ & 3.96 & 5.94 & 3.21 & 6.87 & 4.21 & 11.31 & 2.28 & 5.53 \\
\hline Standard Deviation & 7.51 & 11.81 & 3.96 & 9.80 & 5.88 & 19.70 & 2.48 & 10.59 \\
\hline Number of observations & 32 & 37 & 29 & 21 & 15 & 19 & 5 & 158 \\
\hline $\begin{array}{l}\text { Rolled Over Into IRA } \\
\text { Account balances before retirement (in Wave 1) }\end{array}$ & $\$ 51 \mathrm{k}$ & $\$ 40 \mathrm{k}$ & $\$ 48 \mathrm{k}$ & $\$ 33 k$ & $\$ 48 \mathrm{k}$ & $\$ 72 \mathrm{k}$ & $\$ 8 \mathrm{k}$ & $\$ 43 \mathrm{k}$ \\
\hline Account balances in wave just before retirement & 51 & 43 & 89 & 85 & 79 & 60 & 29 & 44 \\
\hline $\begin{array}{l}\text { Amount of roll over after retirement (at job } \\
\text { termination) }\end{array}$ & 42 & 50 & 105 & 47 & 60 & 65 & 22 & 63 \\
\hline $\begin{array}{l}\text { Ratio: Average roll over after retirement to } \\
\text { Account balances before retirement (in Wave 1) }\end{array}$ & 1.23 & 4.86 & 3.73 & 5.38 & 4.37 & 5.08 & 8.06 & 4.31 \\
\hline Standard Deviation & 1.16 & 8.89 & 3.39 & 9.01 & 4.94 & 7.04 & 10.15 & 6.96 \\
\hline Number of observations & 22 & 38 & 24 & 20 & 17 & 10 & 8 & 139 \\
\hline $\begin{array}{l}\text { Withdrew the Money } \\
\text { Account balances before retirement (in Wave 1) }\end{array}$ & $\$ 11 \mathrm{k}$ & $\$ 464 \mathrm{k} * * *$ & $\$ 12 \mathrm{k}$ & $\$ 13 \mathrm{k}$ & $\$ 6 \mathrm{k}$ & $-* * * *$ & - & $\$ 92$ \\
\hline
\end{tabular}




\begin{tabular}{|c|c|c|c|c|c|c|c|c|}
\hline Account balances in wave just before retirement & 11 & 133 & 16 & 41 & 71 & - & - & 92 \\
\hline $\begin{array}{l}\text { Amount withdrawn after retirement (at job } \\
\text { termination) }\end{array}$ & 6 & 50 & 13 & 25 & 12 & - & - & 21 \\
\hline $\begin{array}{l}\text { Ratio: Average PV of expected benefits to PV of } \\
\text { benefit receipt after retirement }\end{array}$ & 1.92 & 2.50 & 7.54 & 4.09 & 1.80 & - & - & 3.51 \\
\hline Standard Deviation & 2.65 & 2.63 & 12.26 & 4.81 & 1.14 & - & - & 6.44 \\
\hline Number of observations & 25 & 12 & 14 & 10 & 6 & - & - & 67 \\
\hline
\end{tabular}

* The sample includes respondents who reported they left their DC account balance to accumulate, rolled it over into an IRA, or withdrew the money when their job terminated. The sample is restricted to those who reported a DC plan in Wave 1, in the wave just before retirement, and at retirement. DC account balances after Wave 1 are the sum of balances if there was more than one account.

** Observations with a ratio of total benefits that is in the highest and lowest $1 \%$ are excluded.

***One case with a 5.5 million dollar account is in the sample.

$* * * *$ Samples with less than 5 observations are not included. 
Next, we compare pension values reported between the year just before retirement and the year just after job termination. First consider DB pension values. From the last column of Table 6A, row 3 over row 2, DB pension values for respondents who reported receiving benefits at their job's termination are 3.5 percent lower when computed after termination than they are when computed the year before termination. One possibility is that some respondents were ignorant of the effect of spouse and survivor benefits and related options on the annual benefit payment. Only after they retired did they become aware that their annual (not lifetime expected) benefit under a joint and survivor option would be lower than the basic benefit formula as reported by the firm for a single retiree.

Next consider DC pension values. Account values reported just after retirement are 45 percent lower than those reported in the wave just before retirement, even for those whose primary response was that they left the balance to accumulate. But the balance reported after retirement still exceeds the balance reported in the first wave the respondent is in the survey (45/39). One cannot rule out the effects of selection bias here, affecting the choice of plans remaining in the form of continuing DC accounts.

The 3.5 percent reduction in $\mathrm{DB}$ pension value at termination compared to the year before termination helps to explain why pension values measured among retirees are smaller than the pension values measured among those on the job. But this is roughly offset by the increase in present value from the first wave a respondent is in the survey until the wave just before retirement. Thus there is little difference between the wealth value of $D B$ pensions measured in the first wave of the survey and just after retirement. 
Table 7: Present Value of Defined Benefit Plans For Those Who Do Not Receive Benefits Immediately Upon Retiring. Pension Wealth Based on Benefits Expected in Wave 1; Benefits Expected Just After Retirement; and Benefits Eventually Received.

\begin{tabular}{|c|c|c|c|c|c|c|c|c|}
\hline & Wave 2 & Wave 3 & Wave 4 & Wave 5 & Wave 6 & Wave 7 & Wave 8 & Total* \\
\hline \multicolumn{9}{|l|}{ Total Sample } \\
\hline PV expected benefits before retirement (in Wave 1) & $\$ 126 \mathrm{k}$ & $\$ 118 \mathrm{k}$ & $\$ 124 k$ & $\$ 100 \mathrm{k}$ & $\$ 123 k$ & $\$ 71 \mathrm{k}$ & $-* *$ & $\$ 118 \mathrm{k}$ \\
\hline $\begin{array}{l}\text { PV expected benefits after retirement (at job } \\
\text { termination) }\end{array}$ & 114 & 129 & 95 & 71 & 77 & 54 & - & 103 \\
\hline $\begin{array}{l}\text { Average PV of expected benefits after retirement to } \\
\text { PV of expected benefits before retirement Ratio }\end{array}$ & 1.56 & 1.41 & 1.50 & 1.25 & 1.19 & 1.12 & - & 1.43 \\
\hline Standard Deviation & 2.09 & 1.48 & 2.62 & 1.18 & 1.40 & 1.25 & - & 1.89 \\
\hline Number of observations & 57 & 40 & 32 & 23 & 13 & 7 & - & 172 \\
\hline \multicolumn{9}{|l|}{ Group Whose Actual Benefits Were Observed } \\
\hline PV expected benefits before retirement (in Wave 1) & $\$ 148 \mathrm{k}$ & $\$ 129 \mathrm{k}$ & $\$ 124 \mathrm{k}$ & $\$ 102 k$ & $\$ 94 \mathrm{k}$ & $\$ 83 \mathrm{k}$ & - & $\$ 128 \mathrm{k}$ \\
\hline $\begin{array}{l}\text { PV expected benefits after retirement (at job } \\
\text { termination) }\end{array}$ & 129 & 147 & 117 & 68 & 62 & 66 & - & 117 \\
\hline PV of actual benefits from year of first receipt & 130 & 152 & 123 & 69 & 57 & 62 & - & 120 \\
\hline $\begin{array}{l}\text { Average PV actual benefits from year of first } \\
\text { receipt to PV of expected benefits before retirement } \\
\text { Ratio }\end{array}$ & 1.32 & 1.23 & 3.25 & 1.48 & 1.91 & 1.89 & - & 1.73 \\
\hline Standard Deviation & 1.58 & 1.24 & 7.17 & 1.56 & 1.80 & 1.42 & - & 3.39 \\
\hline Number of observations & 43 & 30 & 23 & 17 & 5 & 5 & - & 123 \\
\hline \multicolumn{9}{|l|}{$\begin{array}{l}\text { Ultimately Plan Converted to Cash, IRA, Lost, } \\
\text { dk/rf }\end{array}$} \\
\hline PV expected benefits before retirement (in Wave 1) & $\$ 72 \mathrm{k}$ & $\$ 62 \mathrm{k}$ & $\$ 94 k$ & $\$ 110 \mathrm{k}$ & $\$ 138 \mathrm{k}$ & - & - & $\$ 87 \mathrm{k}$ \\
\hline PV expected benefits after retirement (at job & 79 & 68 & 60 & 78 & 67 & - & - & 68 \\
\hline
\end{tabular}




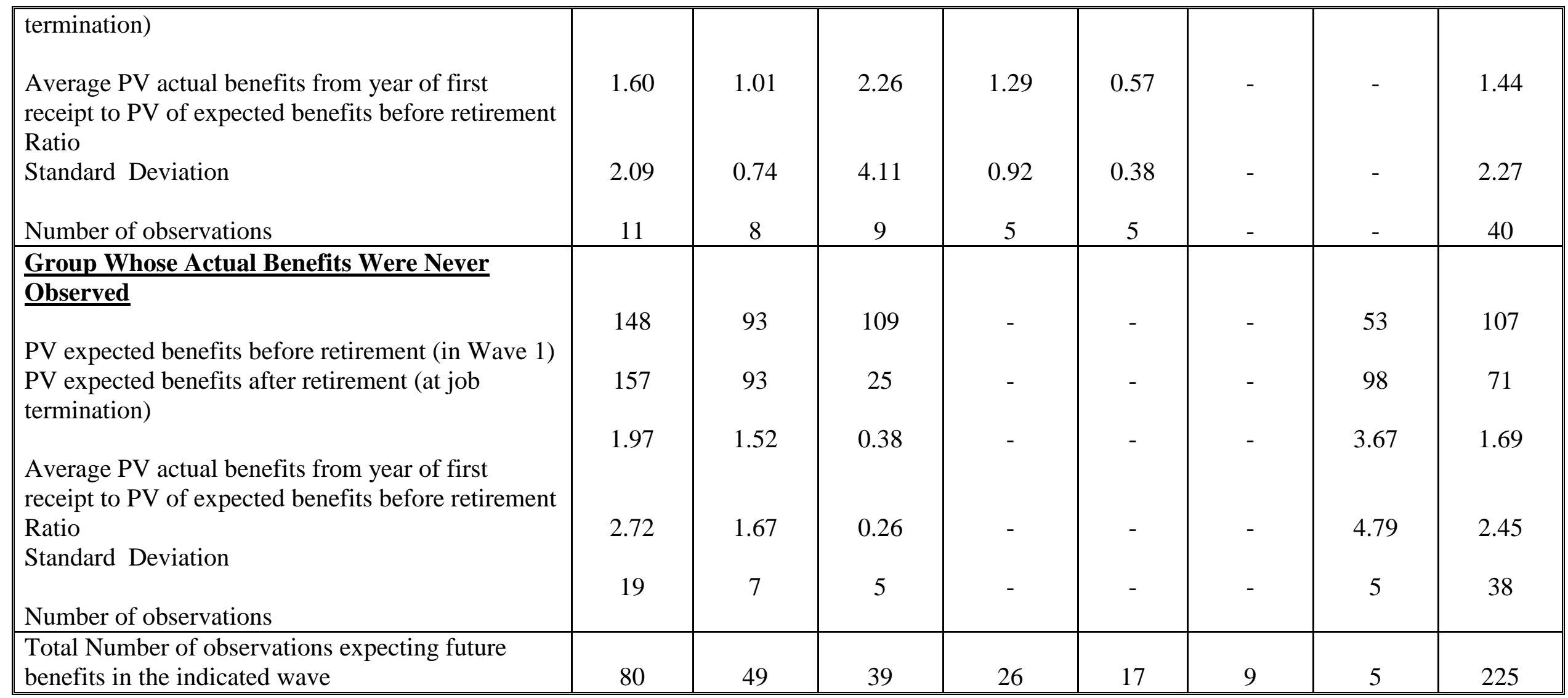

This table is the follow-up to Table 5A. The sample includes only respondents who reported expecting future benefits in that Table, whose plans were not yet in pay status in the interview just after they had left their job.

* Observations with a ratio of total benefits that is in the highest and lowest $1 \%$ are excluded.

**Samples with less than 5 observations are not included. 
Table 7 reports pension wealth for those respondents whose DB plans did not pay benefits immediately upon the respondent leaving covered employment. These plans either began payments some waves after retirement, or had not yet paid a benefit by the eighth wave of the HRS. The three measures of pension wealth are based on: expected benefits as reported in the first wave of the HRS; expected benefits reported just after retirement, but before the plan is in pay status; and actual benefits received at some time after retiring. ${ }^{13}$

Focus on the second panel, which provides results for those whose plan ultimately went into pay status. Pension wealth reported based on observed pension income after retirement is about 2.6 percent higher than the benefits expected, but not yet received, reported in the first wave after retiring. (120/117). For this subsample, however, there are only 123 respondents with data available on pension income after retirement. We found for the 634 respondents in Table 6A who collected benefits immediately after leaving the firm, that benefits declined by 3.5 percent between the amount anticipated just before retirement and the value of pensions reported just after having left the job (139/144).

\section{Conclusion:}

A review of the literature suggests that when pension values are measured by the wealth equivalent of promised DB pension benefits and DC balances for those approaching retirement, pensions account for more support in retirement than is suggested when their contribution is measured by incomes received directly from pension plans by those who have already retired. Our empirical analysis has attempted to account for these differences in the contributions of pensions as measured in income and wealth data.

A number of factors cause the contribution of pensions to be understated in retirement income data.

1. One factor is a difference in methodology between surveys. As pointed out in Anguelov, Iams and Purcell (2012), the CPS ignores irregular payments from pensions. In CPS data on incomes of those

\footnotetext{
${ }^{13}$ Once again, the reported current annual payout is transformed into a present value. And again, we limit the sample to those with only one plan, which is DB, so that mismatching of plans between waves for those with more than one plan is not an issue here.
} 
ages 64 to 69 in 2006, pension values are 58 percent of the value of Social Security. For the same cohort, in HRS data, pension incomes are 64 percent of the incomes from Social Security benefits. According to Iams and Purcell (2013), up to 3 percentage points of this difference may be due to undercounting of irregular withdrawals in the CPS.

2. Some pension wealth "disappears" at retirement because respondents change their pension into other forms that are not counted as pension income in surveys of income. Altogether, 16 percent of pension wealth was transformed into some other form at the time of disposition. For those who had a defined benefit pension just before termination, at termination 12 percent of the respondents had their plans transformed into a state that would not count as pension income after retirement.

3. For those who received benefits soon after termination, there is a 3.5 percent reduction in DB pension value at termination compared to the year before termination. One reason may be the form of annuitization that is chosen. This is another difference contributing to the explanation of why pension values measured among retirees are smaller than the pension values measured among those on the job.

One factor operates in the other direction. Pensions grow in value during the time respondents remain at the firm. Thus there was a 6 percent gain in present values of DB pension between the first wave of the HRS and the year before retirement, as evaluated in 1992. The gain in the value of DC plans was even larger. Consequently, this factor cannot explain why pension values reported by retirees are smaller than pension values reported by current workers.

Our findings suggest a number of caveats. Clearly, reporting errors or inconsistent reporting by respondents play a role in affecting the decline in the relative value of pensions reported as individual's age. Thus there are differences between pension coverage reported before vs. after retirement that appear to lead to exaggeration in the value of pensions before retirement. Altogether, 242 of 2,515 respondents who reported 
pension coverage as of Wave 1 of the HRS denied having pension coverage when they left their job.

Misreporting of plan type also plays a role. Of the 1,602 respondents who reported a defined benefit pension in Wave 1, and who remained throughout the period of analysis, among those who had terminated their job by Wave $8,1,150$ also reported having a defined benefit pension at termination. Thus $452(1,602-1,150)$ members of the survey declared having a pension in Wave 1 and that their pension was a DB plan, but did not declare having a DB pension at the time they terminated their employment on the pension job.

These caveats notwithstanding, the bottom line is that CPS data on pension incomes received in retirement understate the full contribution pensions make to supporting retirees. If one is to avoid understating the role of pensions, a great deal of caution is required. Pension income and wealth measures vary when they are measured for the same person, and for the same pension, at different times in the life cycle. Although part of the difference is due to the well-known discrepancy between expectations and realizations, the documented transitions in pensions over the life cycle are consistent with pensions providing a larger share of support in retirement than is suggested by CPS pension income data.

Understanding the reasons for these differences is important for public policy. The discrepancies between the measures based on income after retirement vs. those based on wealth expected before retirement will lead to an incorrect understanding of how much pensions contribute to supporting families in retirement. Because the contribution of pensions to supporting retirees is understated in CPS income data, both the need for additional support in retirement and the potential contribution of pensions to retirement support may be misunderstood. Errors in measuring the value of pensions in turn lead to errors in the reported share of retirement income due to Social Security. Because pension values are understated, such errors will suggest that retirees are more highly dependent on Social Security for their retirement incomes than they in fact are, and that too large a share of the population of retirees is solely dependent on Social Security. ${ }^{14}$

\footnotetext{
${ }^{14}$ Fisher (2007) has shown there is a similar effect when income from assets is understated.
} 


\section{Selected References:}

Anguelov, Chris E., Howard M. Iams, and Patrick J. Purcell. 2012. "Shifting Income Sources of the Aged." Social Security Bulletin, 72(3): 59-67.

Bricker, Jesse, Arthur Kennickell, Kevin B. Moore, and John Sabelhaus. 2012. "Changes in U.S. Family Finances from 2007 to 2010: Evidence from the Survey of Consumer Finances," Federal Reserve Bulletin, June 2012.

Bricker, Jesse, Brian Bucks, Arthur Kennickell, Traci Mach, and Kevin Moore. 2011. "Surveying the Aftermath of the Storm: Changes in Family Finances from 2007 to 2009.” Paper 2011-17, Finance and Economics Discussion Series, FRB, Washington, DC, 2011.

Dushi, Irena, and Marjorie Honig. 2008. How much do respondents in the Health and Retirement Study know about their tax-deferred contribution plans? A cross-cohort comparison. Working Paper No. 2008-201. Ann Arbor, MI: Retirement Research Center at the University of Michigan.

Fisher, T. Lynn. 2007. “Estimates of Unreported Asset Income in the Survey of Consumer Finances and the Relative Importance of Social Security Benefits to the Elderly." Social Security Bulletin 67(2): 247-253.

Gustman, Alan L., Olivia S. Mitchell, Andrew Samwick and Thomas L. Steinmeier, 1999. "Pension and Social Security Wealth in the Health and Retirement Study". In James Smith and Robert Willis, editors, Wealth, Work and Health, Innovations in Measurement in the Social Sciences. Ann Arbor: University of Michigan Press, 1999, pp. 150-208.

Gustman, Alan L. and Thomas L. Steinmeier. 1999. "Effects of Pensions on Savings: Analysis with Data From the Health and Retirement Study”. Carnegie-Rochester Conference Series, vol. 50 (July, 1999) pp. 271326. 

. 2004. "What People Don’t Know About Their Pensions and Social Security". In William

G. Gale, John B. Shoven and Mark J. Warshawsky, editors, Private Pensions and Public Policies. 2004.

Washington: D.C., Brookings Institution, pp. 57-125. . 2005. "Imperfect Knowledge of Social Security and Pensions." Industrial Relations.

Vol. 44, No. 2 (April, 2005): 373 -395.

Gustman, Alan L., Thomas L. Steinmeier and Nahid Tabatabai. 2010a. Pensions in the Health and Retirement Study. Cambridge: Harvard University Press. . 2010b. "What the Stock Market Decline Means for the Financial Security and Retirement Choices of the Near-Retirement Population." Journal of Economic Perspectives 24(1): 161-182. Iams, Howard M. and Patrick J. Purcell. 2013. "The Impact of Retirement Account Distributions on Measures of Family Incomes". Social Security Bulletin 73(2): 77-84.

Poterba, M. James, Steven F. Venti and David A. Wise. 2011. "The Drawdown of Personal Retirement Assets”. NBER Working Paper No. 16675. Cambridge, MA: National Bureau of Economic Research. Social Security Administration. Various Years. "Income of the Population 55 or Older". 
Appendix 1: The variables in Table 2 and subsequent tables are defined as follows:

\section{Total Income from HRS}

1- Total income from HRS is the sum of earnings and income from respondent and spouse, including individual earnings, income from employer pension or annuity, income from Social Security DI or SSI benefits, income from Social Security retirement benefits, unemployment insurance, workers compensation, income from other government transfers, household capital income, and all other household income.

2- Total wealth includes the present value of Social Security benefits, pensions from current and any previous jobs, primary and secondary housing, real estate, IRAs, financial assets, businesses, and vehicles.

\section{A- Social Security}

1- Social Security Income in the HRS includes income from Social Security retirement, spouse or widow benefits, and SSI and DI benefits. It is calculated based on the amount of benefits received last month. It is reported in the Assets and Income section of the survey.

2- Social Security benefits in CPS data include Social Security retirement, spouse and widows' benefits, as well as Disability Income and transitionally insured benefits.

3- Present Value is calculated based on an "if claim now" scenario. It includes the present value of the benefit for the respondent, his/her spouse, any top ups, and those benefits already claimed.

\section{B- Pension}

1- Pension Income from HRS includes income from all pensions and annuities. Irregular payments are included if they were paid out the month before the financial respondent in the household was interviewed.

2- CPS data excludes irregular payments from IRA, 401k, and Keoghs.

3- Present Value of pension includes:

a. The present value of expected future benefits from all previous pensions. It is constructed based on the value reported by respondents when they were first interviewed, or in the wave after a job offering a pension was terminated. The present values are computed using a single life table from the Social Security Administration and a 5.8 percent interest rate. Values are updated by $5.8 \%$ for each year between the year it was reported and 2006.

b. The present value of pensions for plans already in pay status includes the present value of remaining benefits as of 2006.

c. DC account balances from last and previous jobs that were left to accumulate are included in pension wealth. Their values are updated by 5.8 percent for each year between the year they were reported and 2006. 
Appendix Table 1: Effects of Attrition on the Panel Data

\begin{tabular}{|l|c|c|c|c||}
\hline Samples & $\begin{array}{c}\text { Number of } \\
\text { Obs. with a } \\
\text { DB Plan }\end{array}$ & $\begin{array}{l}\text { PV of expected } \\
\text { benefits (DB) in } \\
\text { Wave 1 }\end{array}$ & $\begin{array}{c}\text { Number of } \\
\text { Obs. with a } \\
\text { DC Plan }\end{array}$ & $\begin{array}{l}\text { Account } \\
\text { balances in } \\
\text { Wave 1 }\end{array}$ \\
\hline \hline All* & 2022 & $\$ 112 \mathrm{k}$ & 1277 & $\$ 39 \mathrm{k}$ \\
\hline $\begin{array}{l}\text { Terminated Wave 1 job after } \\
\text { Wave 1 \& before Wave 8 }\end{array}$ & 1602 & 114 & 991 & 38 \\
\hline $\begin{array}{l}\text { Left the survey after Wave 1 } \\
\text { \& before terminating Wave } \\
1 \text { job }\end{array}$ & 243 & 107 & 141 & 32 \\
\hline $\begin{array}{l}\text { Did not leave and did not } \\
\text { terminate Wave 1 job }\end{array}$ & 177 & 96 & 145 & \\
\hline
\end{tabular}

*The sample includes respondents with one pension plan from a current job in Wave 1. There are 90 cases who reported their plan type as both DB and DC. 